\title{
Transforming ESL Teaching Modalities Using Technological Tools
}

\author{
Saeid Angouti ${ }^{1} \&$ Karim Jahangiri ${ }^{2}$ \\ ${ }^{1}$ School of Economics and Management, Nanjing University of Science and Technology, Nanjing, China \\ ${ }^{2}$ School of English Language and Literature, Miyaneh Azad University, Miyaneh, Iran \\ Correspondence: Saeid Angouti, Nanjing University of Science and Technology, 200 Xiaolingwei, Nanjing \\ 210094, P.R. China. E-mail: saeid279@outlook.com
}

Received: January 2, 2019 Accepted: January 23, 2019 Online Published: January 29, 2019

doi:10.5539/ells.v9n1p134 URL: https://doi.org/10.5539/ells.v9n1p134

\begin{abstract}
A qualitative approach was used to analyze the effect of technology on enabling ESL students to grasp new content. The major objective of this research was to explore the techniques and strategies implemented by ESL tutors. The research also identified the technological tools such as smart board computers, and tablets that ESL teachers can use in passing information so as to allow students relate with whatever is being taught. Data was collected through conducting interviews on two ESL tutors who are highly experienced, and by conducting an in-depth literature review. In the findings, four themes became evident. They are; 1) Numerous techniques are applicable in teaching ESL such as tablets, computers, and smartboards; 2) A major benefit of incorporating technology in ESL is higher independency rates among students 3) Various challenges are normally faced by the tutors when using technology to teach ESL including lack of knowledge on how to use the provided technology, poor student engagement, failure of emerging technologies in being user friendly, and off-task behavior. 4) Teachers, parents, and students appreciate the use of technology in teaching and learning. Moreover, this research reviewed the specific strategies that are applied by teachers so as to ensure that there is better receptivity amongst students. This research paper is intended to help provide a better understanding to tutors who may want to incorporate technology in teaching ESL.
\end{abstract}

Keywords: English as a Second Language, English Language Leaners, technology, differentiated instruction

\section{Introduction}

\subsection{The Problem}

Analysis shows that America and surrounding countries continue to be diverse as people from different backgrounds stream into the region in search of jobs and academic advancement. For instance, a high percentage of Canadians are either immigrants, or they are descendants of a long lineage that came into Canada many years ago. Statistics Canada indicates that approximately 242,000 persons are given letters of permanent residency in Canada on an annual basis. Approximately one fifth of the population doesn't speak fluent English and have another supportive language (Statistics Canada, 2011). Since English can easily be learned, a high number of immigrants want to learn the language. Therefore, advanced approaches have to be employed in supporting the large population that needs to study English as a Second Language (ESL).

Some of the people who have been born and bred in Canada also need support since English is not the only native language in the country (Erben, Ban, \& Castañeda, 2009). On the other hand, students who move to Canada on scholarship basis have to be fluent in English Language so that they can relate with tutors and other students properly. The society is immersed in a technological environment. Therefore, it is essential that tutors and parents be able to provide students with knowledge on how technological devices can be exploited in a manner that allows better comprehension of English language (Sabzian \& Gilakjani, 2013). The following chart shows steps that are taken to identify potential English learners in different states within the US. The continuous increase in demand for ESL studies calls for better teaching modalities as the pen and paper approach fails to address the most critical needs of ESL leaners (Falk \& Blumenreich, 2005). 


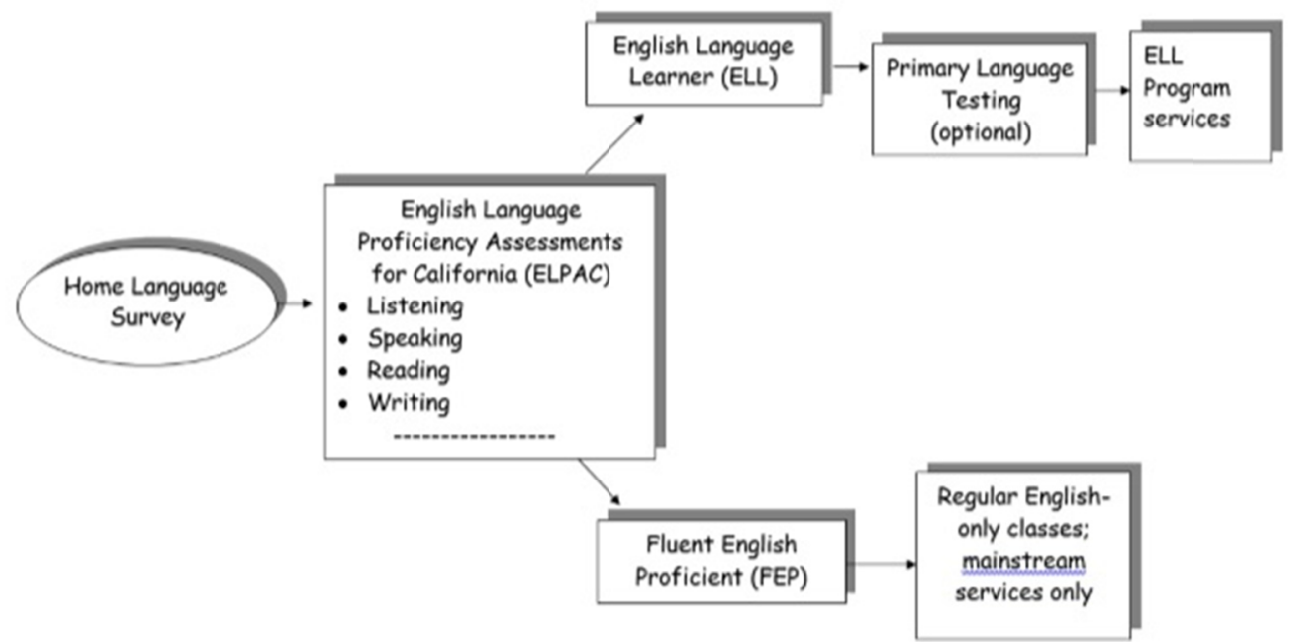

Figure 1. Initial placement flow chart for students new to California

Source: https://www.powayusd.com/PUSD/media/LSS/ELL/PUSD-EL-Master-Plan-Final-2018.pdf

\subsection{Purpose of the Study}

The primary purpose of conducting this research is to create a better understanding of ESL learners' requirements, and different approaches that ESL tutors can employ in order to encourage better acquisition of the English language. The study will precisely focus on how technology can support the overall academic success of ESL learners in a classroom that is highly inclusive, rather than when using a withdrawal/pull down program.

\subsection{Research Questions}

The primary research question is; what role is played by technology in supporting ESL leaners in a classroom?

The sub questions that support the primary research question are;

1) What are the strategies and methods that are used by ESL tutors in order to encourage high levels of engagement from learners?

2) How does technology support tutors who are involved in teaching ESL?

3) How does technology support ESL learning within a classroom setting?

4) What are the primary technological tools that can be used to support ESL students within an inclusive class?

5) What are the major challenges that teachers face when using technology to teach ESL?

6) What kind of perception do students, teachers, and parents have with regards to using technology in an ESL classroom?

\section{Relevant Research and Concepts}

English Language Learners (ELL) are defined as students for whom English is not first language. Such students have extensive backgrounds in culture and school experience, and this provides them with unique strengths as well as needs. Most students who intend to study English as a Second Language may not necessarily be from outside a country where English is spoken. They may have been born in an English-speaking nation, but since they belong to a community that doesn't embrace English as a first language, they end up requiring intensive tutoring to enable them have a better comprehension of the English language (Jung \& Suhyun 2012). It is essential that ESL leaners be taught the Instructional Language in English since they are mandated to complete a curriculum that helps them to become proficient in using English terminologies (Turner, 2010). The chart shows the most common strategies that ESL tutors can employ in class. Role plays enables ESL leaners to comprehend suitable approaches of relaying instructions in English. 


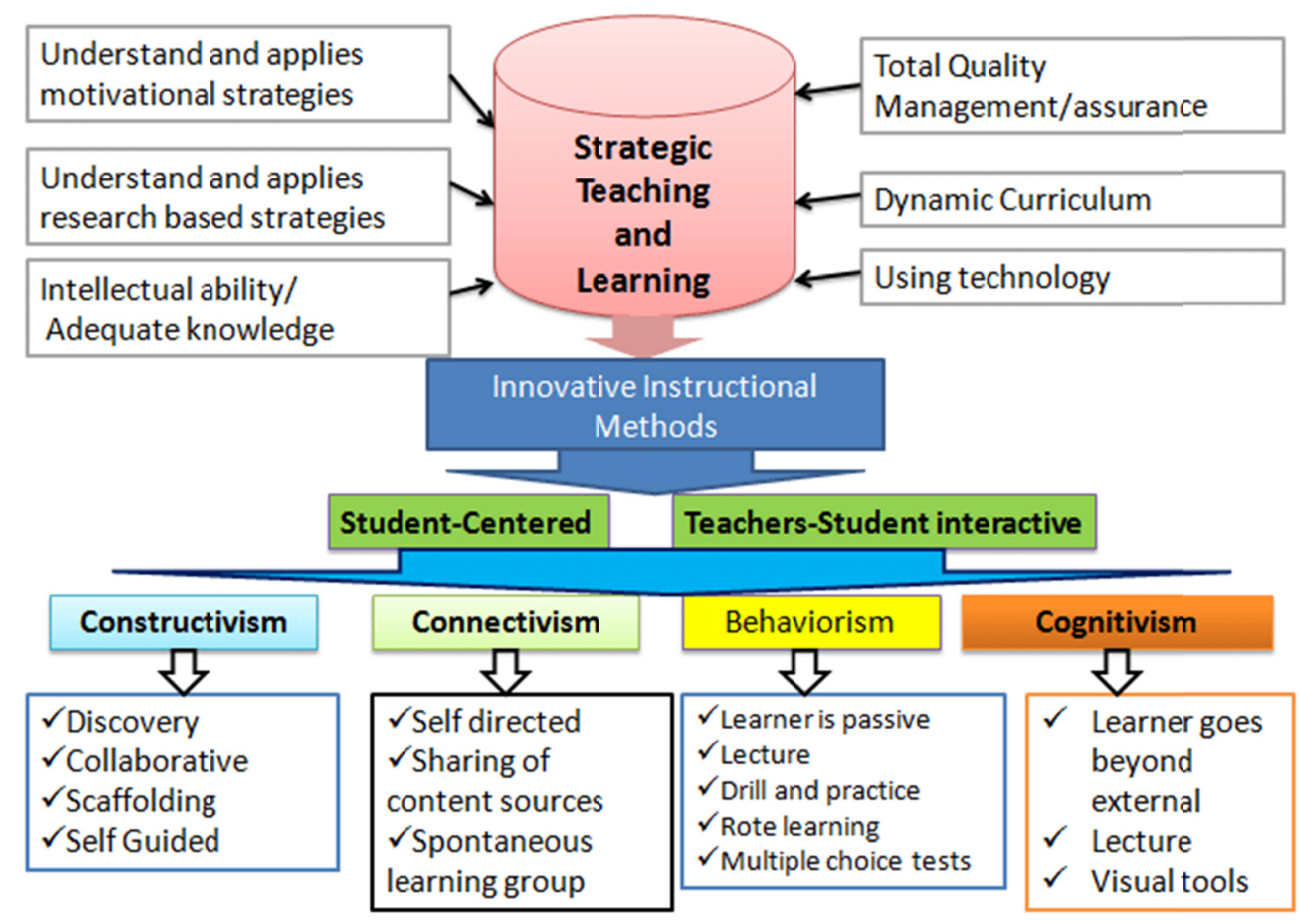

Figure 2. Pedagogical teaching strategies

Source:

https://www.researchgate.net/figure/Strategic-Teaching-and-Learning-Approach-Towards-Sustainable-Engineeri ng-Education_fig2_320215842

English Language Learners may learn the language over different time periods. For moderate fluency to be adopted, approximately two years are needed, while about five years are needed for an ELL to become as fluent as a native English speaker. Suitable approaches and strategies need to be adopted in relaying English to ESL learners since this is the determinant between developing a positive or negative attitude (Falk \& Blumenreich. 2005). The following charts shows the current approach that is used to assess the skill level of new ESL students. In order for teachers to understand a particular students' requirements, their skill level in writing and speaking must be understood. Analyzing ESL/ELL students' skills enables a teacher to understand the most suitable approach that can be adopted while in the classroom environment (Kenney, 2011). 


\section{Initial assessment of reading and writing}

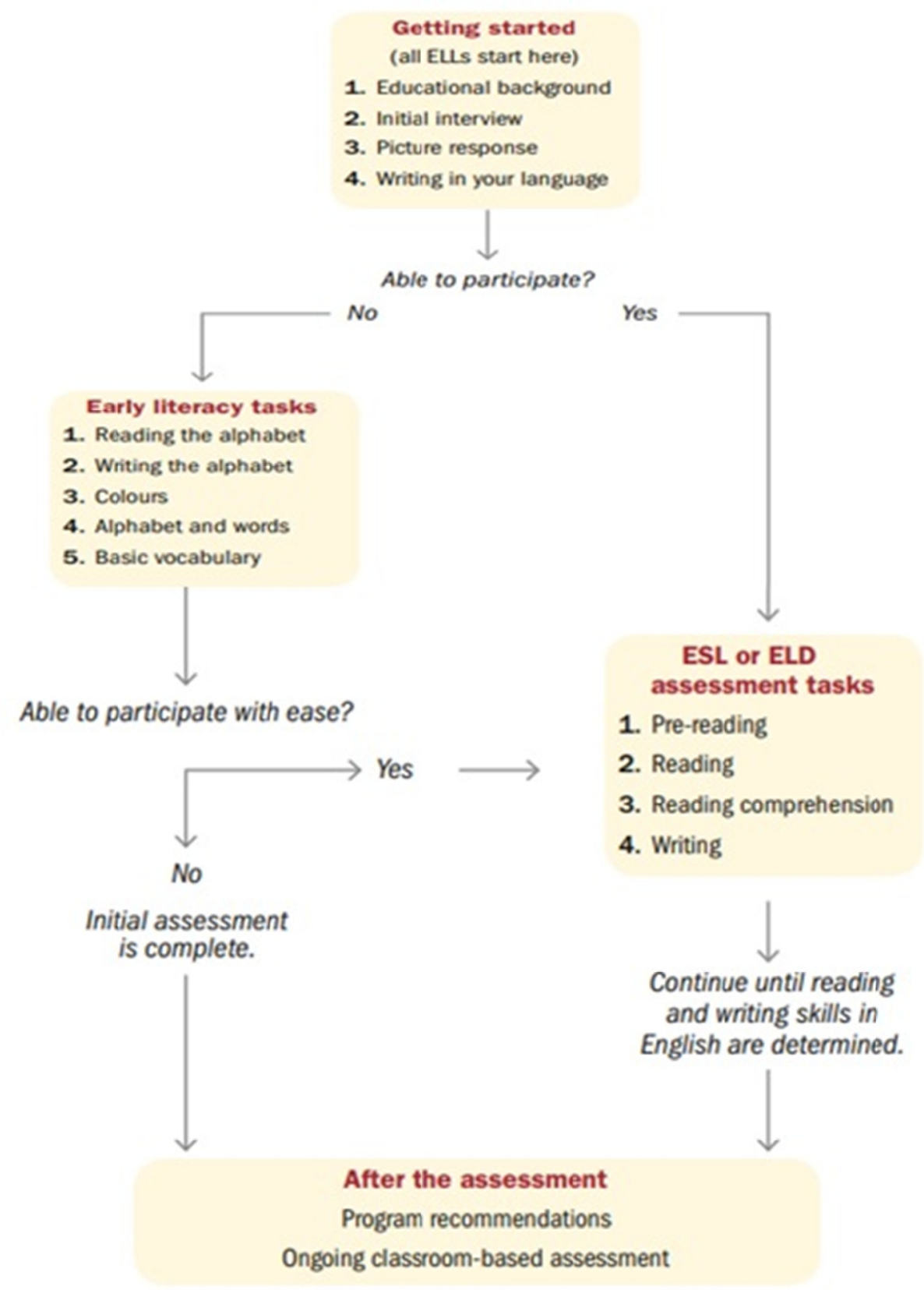

Figure 3. Student assessment chart (Ontario 36)

Source: Ontario Ministry of Education. (2008). Supporting English Language Learners: A Practical Guide for Ontario Educators, Grades 1 to 8, pp. 34-38.

\subsection{Technology in the Classroom}

Many institutions appreciate the use of technology in classrooms in orderto improve how instructions are passed to the students. When students are introduced to technology early enough, just like when a child is introduced to their native language when he/she is still young, then a learner is able to engage easily with the tool that is to be used. According to Briggs (1998), when children are allowed to teach each other using technology, the latter provides them with an enriching and affirming learning environment. Utilizing technology in teaching ESL is therefore, unarguably suitable since it can offer a meaningful approach for the learning process. 


\section{Suitability of Technology in the Classroom}

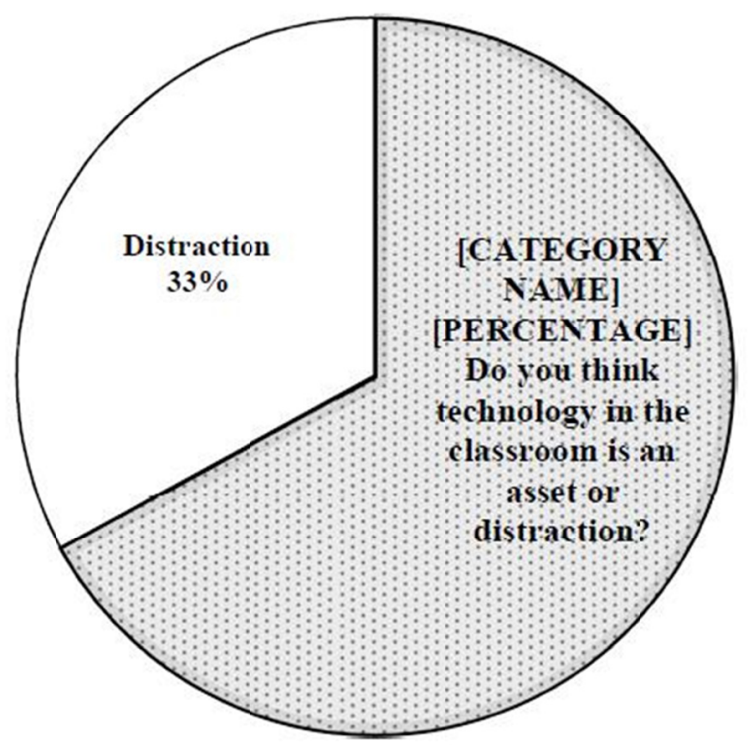

Figure 4. Suitability of technology in the classroom

Source: http://www.vsuspectator.com/2015/10/27/millennials-in-the-classroom/

Technology motivates students to learn while being encouraged to read, speak, listen, and easily write (Ilter, 2009). Turner (2010) proposes that approximately $67 \%$ of teaching staff believes that technology can be an invaluable asset in the classroom. However, using technology is not fully sufficient in allowing ESL students comprehend the English Language. A teacher who has very clear objectives should be present, and he/she should be able to offer students with learning experiences that allow them to develop a passion for the new language (Schwartz \& Pollishuke, 2013).

\subsection{Computer Assisted Language Learning}

Before being able to use technology in teaching English Language, teachers should understand the most common terms that are associated with technology. They include CALL (Computer Assisted Laguage), TELL (Technology Enhanced Language), and CELL (Computer Enhanced Language Learning). Most importantly, tutors should create an approachable environment that encourages learning and better association with the students (Egbert, 2005). At no point can the teacher be substituted by the technology that is being used as both support each other in delivering instructions to the students in a manner that allows the latter to comprehend better. Technology can be used in different ways within the classroom. However, student involvement should always be encouraged so as to create an authentic learning experience (Egbert, 2005).

\section{Methodology}

\subsection{Procedures}

This research used a qualitative research approach since the primary objective was to develop a greater understanding of the strategies and methods that are currently used by instructors to assist ESL learners. Qualitative research is highly naturalistic as it assists in understanding an event that happens in a specific setting. In this case, the qualitative approach is essential since it will provide a clear understanding of a phenomenon that is almost unknown. The research data was also provided by additional research on ESL, and a study with the technological tools that tutors use in modern class settings.

Information for the relevant research section was obtained from databases such as CRCA, ERIC, and Summon. Next step involved conducting interviews on two ESL tutors where one was done through Skype and the other on a face to face basis. The interview was essential as it helped understand the approaches that are used in class and how ESL teachers interact with their students in a technologically enabled environment. The final step involved a critical review of the interview transcripts.

\subsection{Data Collection Instruments}

A General interview technique was used when questioning the participants (Turner, 2010). This approach allows 
for gathering sufficient data on the general topic. Doing this enabled us to focus on specific pre-set questions. At the same time, the interviewees were allowed some freedom and adaptability. The goal in this case was to collect sufficient information from a less experienced tutor on student understanding of English Language when technology is used in a classroom. Additionally, it also allowed us to collect data from a highly experienced tutor who has been involved in educating ESL students within a withdrawn environment.

During the interview process, the focus was on two aspects. First of all, to gain information from a teacher who is in the process of teaching ESL students using technology as this would enable understand the current conditions within ESL classrooms. Secondly, to understand the progression of using technology in ESL classrooms, as this would provide me with extensive information on the changes that have occurred over time. Therefore, the first participant had a 20-year experience in teaching ESL, while the second participant was a teacher who was practicing ESL teaching in Toronto.

\subsection{Data Collection and Analysis}

In an ongoing research process such as this one, data analysis starts off the moment it is collected. Once data is collected, it is essential to review and reflect on the collection process (Falk \& Blumenreich). For the purpose of data analysis, the data was transcribed using Express Transcriber. The next step involved feeding data into an excel spreadsheet that had three columns. The research questions were copied onto the Excel sheet so as to relate them with the acquired responses. After completing the transfer of information onto the Excel file, data was categorized based on the previously identified themes. This process allowed us to see how the identified themes were related with the collected Data. Afterwards, the data was organized into a table created with Word Processor. While classifying, describing, and interpreting data, we created codes that allowed for proper categorization of the data y (Ramsay, 2011). Information that did not make sense was discarded, thenthe data was divided based on codes, themes, and categories initially developed within the Excel file.

\section{Findings}

After conducting an in-depth analysis of the feedback provided by the research participants, the following four primary themes were identified;

1) Numerous teaching approaches are used by ESL tutors and the most common technologies that are used in the process include smart boards, computers, and tablets.

2) There are various benefits of using technology. The main one is improvement in independence levels amongst the students.

3) Challenges that are resolvable do exist when trying to relay instructions to the students. The highest challenge in this case revolves around the inability to understand the technology.

4) Teacher, students, and parents have a positive perception with regard to using technology in the class.

\subsection{Theme 1}

Based on the feedback that I acquired from my interviewees, the following strategies appear to be intensively used within the classroom;

1) Equitable literary approach

2) Parents-students utilization of the first language

3) Employing different technological tools within the class setting

4) Visual Scaffolding

5) Emphasizing on routines within a class environment

6) Encouraging students to be patient and tolerant

7) Keep in touch with homeroom teacher and encourage them to support ESL teaching processes. 


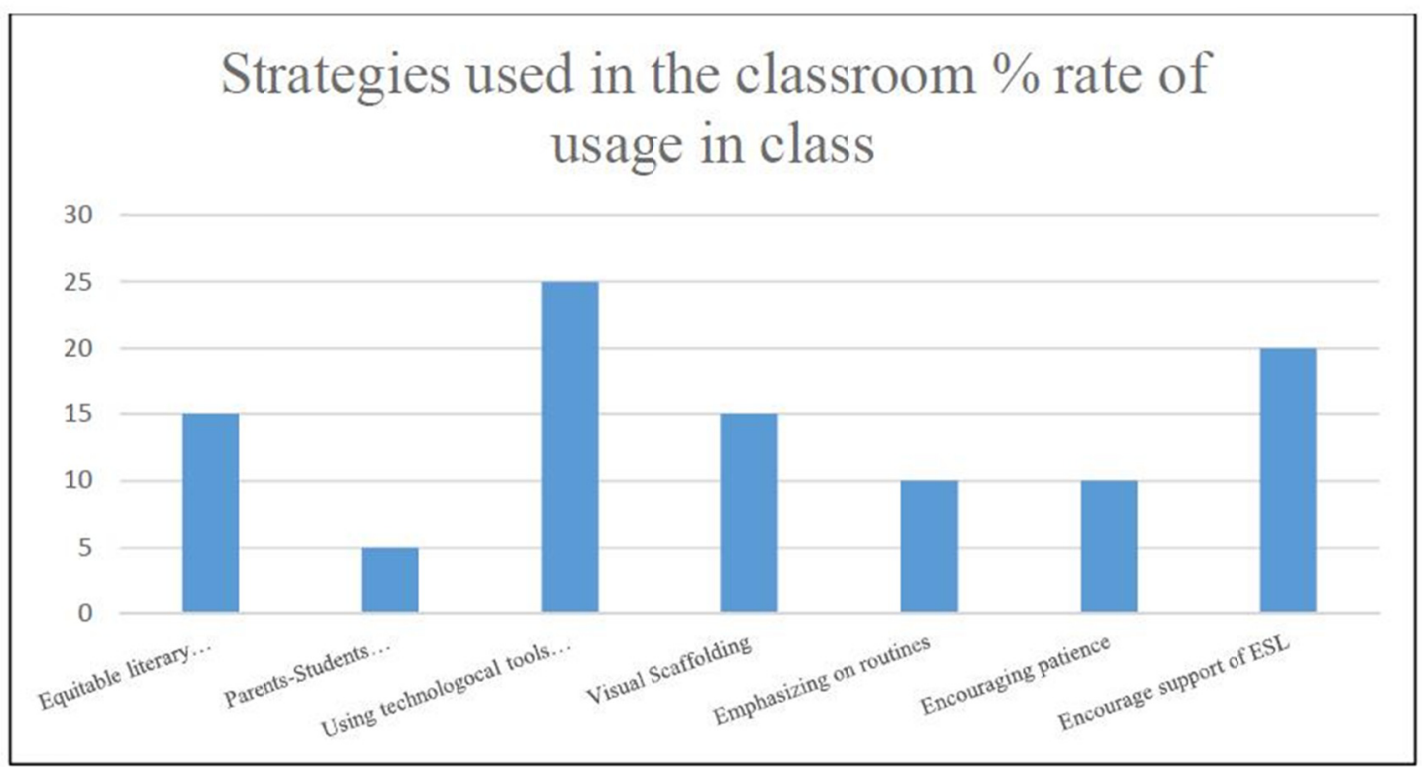

Figure 5. Rate of usage of ESL teaching modalities

Both respondents said the most important factor in ESL teaching profession is having a character of patience. While both groups have expectation of each other, tolerance and patience are two very important aspects in the classroom. When an atmosphere of tolerance is established, then students gain the confidence to air out their needs. This allows the tutor to understand the student progress. When students feel comfortable with their environment, they become motivated to take bigger risks in the effort to learn and develop new language skills. Hubbard and Whitsett (2009) argue that tutors who appreciate the students' values send an unspoken message that the best performance is expected. On the other hand, the students end up reciprocating this environment by working hard to succeed.

\subsection{Theme 2}

Based on the feedback obtained from the two interviewees, the following major benefits of using technology in the process of teaching ESL were identified.

1) Students are provided with greater room for expressing themselves, and this boosts their skill and language levels.

2) Technology leads to higher motivation levels, self-confidence, and independence.

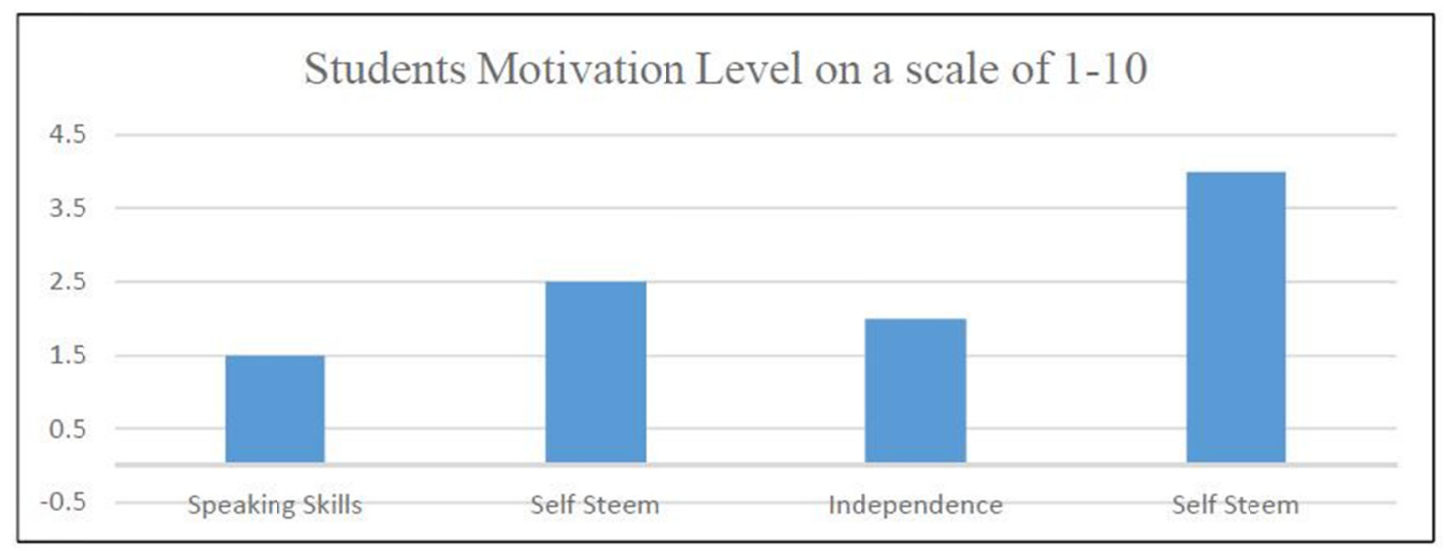

Figure 6. Comparison of motivation levels on ESL students' as a result of using technological tool 
In this case, technology allowed the learners to continually practice whatever they had been able to learn when they are inside and outside the classroom. It allows students to express themselves in more than just one way. This provides greater opportunities for the leaners since they can be able to take photos or record audio voices so that they can learn from these processes (Lepi, 2013).

Both respondents agreed that the use of technology in their classes allows students to become independent very quickly. The first respondent said that understanding the use of a technology be it an app or the computer offered students with a classroom setting that is inclusive. The second respondent said that technology offers students a safe environment for practicing their skills. Approaches such as Scaffolding offers students with visuals that allow them to take reasonable risks while trying out their language (Patnoudes, 2012).

\subsection{Theme 3}

Both interviewees admitted to being faced with complications while trying to educate ESL students using technology, and they highlighted the following issues;

1) Unfriendly technologies being introduced to the process of teaching

2) Technical failures and difficulties

3) Off-task tendencies and Low student engagement

4) Unfamiliarity of the provided technology

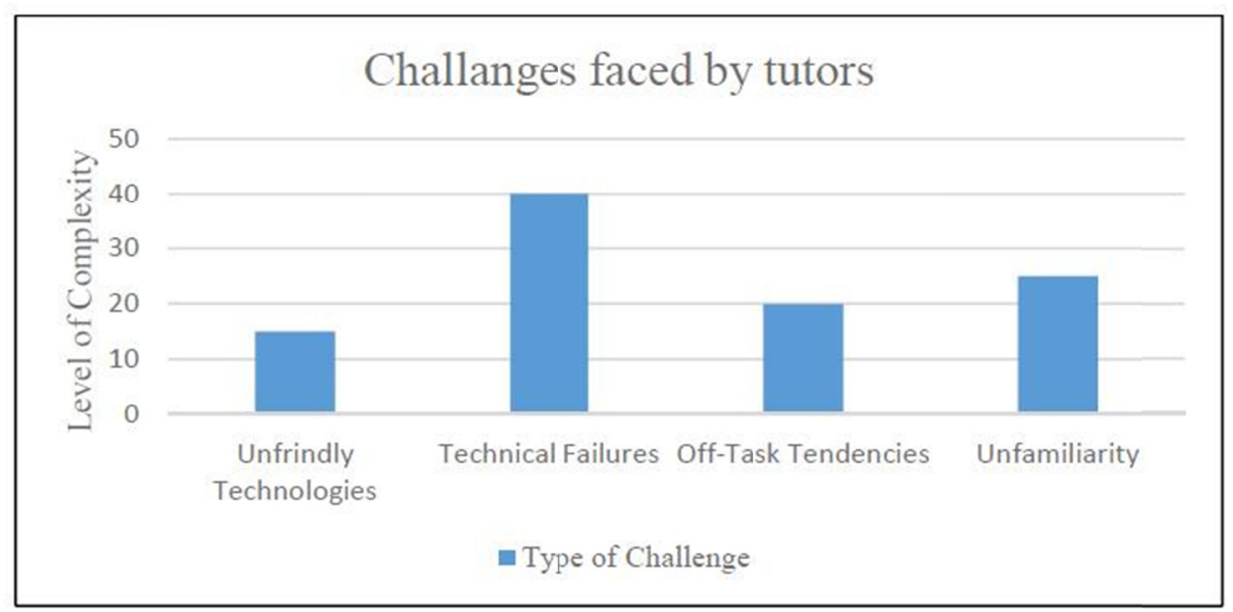

Figure 7. Different challenges that ESL tutors face

A huge distractor when trying to integrate technology into any industry is the possibility to encounter challenges (Kenney, 2011). When this happens, it may discourage users from enjoying the interaction process. The more a technology fails, the more it provides us with an environment for understanding it better. Susan (1997) proposed that in most teaching scenarios, tutors are left to gain technological skills by themselves instead of using a pre-set design. The challenges and tasks that they encounter when teaching using operating systems and apps provide them with an environment of learning the system deeply. Although this is a slow approach, it always ends up working. However, sometimes this approach may be discouraging both for the tutors and students.

\subsection{Theme 4}

Both research participants agreed to the fact that the teachers, parents, and students exhibit a positive reaction upon the introduction of technology in the classroom. Julie Ramsay (2011) argues that the current society has different expectations, which are different from those that used to exist in the past. Julie Ramsay (2011) proposed that learning through writing serves a greater purpose than just helping students become prepared for future life engagements. When students are offered a platform that can allow them to learn and lead during a class session, they become very motivated. Using technology in class ensures that skills for future life are gained (Ramsay, 2011). 


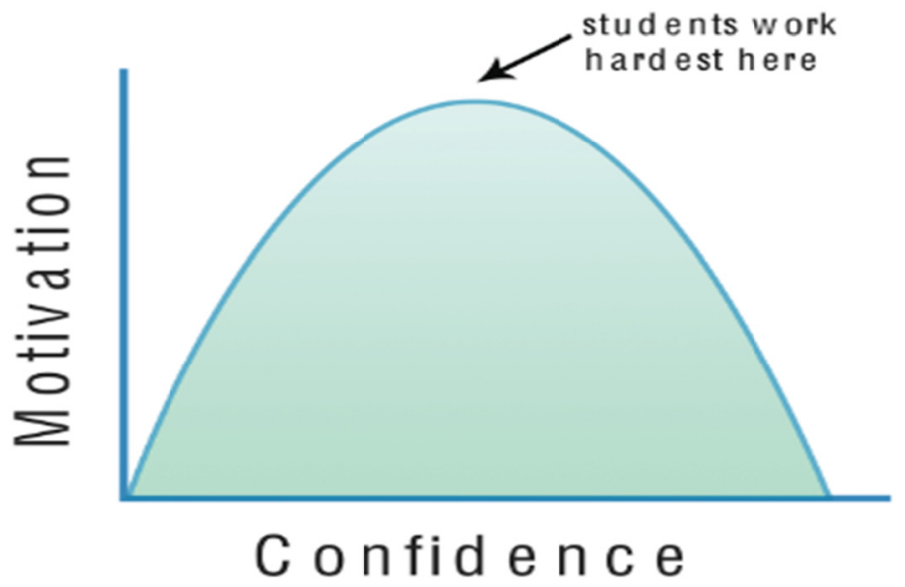

Figure 8. Confidence buildup as a result of using Technology

Source: http://www.efoza.com/post_motivational-charts-or-graphs_177789/

Focus in the current society has been directed on the C's (Collaboration, Creativity, Communication, Citizenship and Critical Thinking) that are associated with education (Meskill, 2005). Students expect that by the end of the classroom session they will be able to employ critical thinking, communicate, and collaborate in the process of solving problems. Likewise, the same expectation is held onto by parents and teachers.

\subsection{Summary}

While the two participants are not related, they concluded that apart from the improvement in self-confidence, technology allows ESL learners to boost their English-speaking skills.

\section{Discussion}

This research was initially conducted with interest in understanding how ESL tutors employ technology within classroom settings. However, it ended up with becoming more interested on how technology has impacted the teaching process of ESL, and its greater importance in such an environment. Technology can play the mere role of a tool. However, if it is properly implemented, it may lead to greater advantages being acquired. This study revealed that technology is a useful tool that can help ESL students easily cement the acquired knowledge.

Based on the relevant research section, approximately one fifth of the population in Canada can speak more than just English. On the other hand, about three quarters of Elementary schools in Ontario (60\%) plus the secondary schools have ESL students. This alone makes the number of ESL students in Ontario to be approximately 85\% of the total ELL learners in Canada. Therefore, it is necessary to ensure that more resources, including teacher skills, are directed towards teaching ESL worldwide. Most of the challenges that are being encountered in teaching ESL revolve around technological aspects (Ilter, 2009).

\section{Conclusion}

Most teachers have little knowledge of how technology can be incorporated in the process of enhancing, teaching, and learning ESL. Secondly, the absence of sufficient funds curtails the integration of technology into the process of educating ESL students. Lepi (2013) suggests that teachers adore education technology, but they tend to use it less often. Other factors that have been identified as being the biggest contributors of the failure to integrate technology in ESL includes absence of well skilled staff, little training being offered to teachers on how they can use technological tools to successfully teach ESL in the classroom, and very little time being offered during the implementation phase (Patnoudes, 2012). This study showed that technology allows ESL students to learn English language more confidently since they don't fear criticism from peers.

\section{Limitations}

This study was faced by certain limitations, which mainly around the sample size for interview that is used. Although sufficient amount of data was gained from those who were involved in teaching ESL using two different approaches, we believe that questioning a large group of participants would have helped us to 
understand the topic at hand much better. There was also a time constraint as I was forced to undertake this research process in a period of two years while still having to engage myself in a very demanding education program.

\section{Acknowledgements}

I would love to acknowledge my supervisor who guided me through this process, Dr. Karim Jahangiri, who has now become a very close friend and mentor. Apart from just directing me in my project, my interactions with him have enabled me to learn numerous lessons that I would otherwise not have been able to gain. I am also grateful to the institution for allowing me to undertake this research process and offering me financial support to undertake this research.

\section{References}

Confidence buildup as a result of using Technology. Retrieved September 15, 2018, from www.efoza.com/post_motivational-charts-or-graphs_177789/

Erben, T., Ban, R., \& Castañeda, M. E. (2009). Teaching English language learners through technology. New York: Routledge.

Falk \& Blumenreich. (2005). Making sense of your learnings analyzing data. In The Power of Questions (pp. 115-133). New York, New York: Heinemann.

Ilter, B. G. (2009). Effect of technology on motivation in EFL classrooms. TOJDE, 10(4), 1. Retrieved from http://tojde.anadolu.edu.tr/tojde36/articles/article_9.htm

Jung, W. H., \& Suhyun, S. (2012). Making learning active with interactive technology in ELL classrooms. Computers in the School. Interdisciplinary Journal of Practice, Theory, and Applied Research, 29(4).

Lepi, K. (2013). Study: Teachers love EdTech, They just don't use it. Edudemic. [Blog post]. Retrieved from http://www.edudemic.com/teachers-edtech-study/

Meskill, C. (2005). Triadic scaffold: Tools for teaching English language learners with computers. Language Learning and Technology, 1(9), 46-59.

Ontario Ministry of Education. (2008). Supporting English Language Learners: A Practical Guide for Ontario Educators, Grades 1 to 8, pp. 34-38.

Patnoudes, E. (2012). How to integrate education technology with scaffolding. Edudemic. [Blog post]. Retrieved from http://www.edudemic.com/scaffolding-education-technology/

Pedagogical Teaching Strategies. Retrieved September 15, 2018, from www.powayusd.com/PUSD/media/LSS/ELL/PUSD-EL-Master-Plan-Final-2018.pdf

Ramsay, J. D. (2011). Can we skip lunch and keep writing? Portland, ME: Stenhouse Publishers.

Sabzian, F., \& Gilakjani, A. P. (2013). Teachers' attitudes about computer technology training, professional development, integration, experience, anxiety, and literacy in English language teaching and learning. International Journal of Applied Science and Technology, 1(3), 67-75.

Suitability of technology in the classroom. Retrieved September 15, 2018, from www.vsuspectator.com/2015/10/27/millennials-in-the-classroom/

Turner, D. W. (2010). Qualitative interview design: A practical guide for novice investigators. The Qualitative Report, 15(3), 754-760.

Linguistic Characteristics of Canadians. Retrieved https://www12.statcan.gc.ca/census-recensement/2011/as-sa/98-314-x/98-314-x2011001-eng.cfm

Briggs, D. (1998). A class of their own: When children teach children. Westport, Connecticut: Bergin \& Garvey.

Kenney, L. (2011). Elementary Education, There's an App for That: Communication Technology in the Elementary School Classroom. 


\section{Appendix A}

\section{Interview Questions}

1) How long have you been in the teaching profession?

2) What philosophy do you adopt in the process of teaching?

3) Approximately how long have you been involved in teaching ESL?

4) What Strategies do you adopt in the process of teaching ESL?

5) In a Single day, approximately how many times do you incorporate technology while teaching?

6) What kind of feedback do you usually get from ESL learners?

7) Which Technological tools do you employ in the classroom while teaching ESL?

8) Is there a particular program that has been rolled out for use while teaching ESL?

9) Are there any other approaches that you are used by your colleagues when teaching ESL?

10) What advice would you give with regards to the use of technology while teaching ESL?

\section{Copyrights}

Copyright for this article is retained by the author(s), with first publication rights granted to the journal.

This is an open-access article distributed under the terms and conditions of the Creative Commons Attribution license (http://creativecommons.org/licenses/by/4.0/). 